\title{
THE VEGETATION OF FLOODPLAIN IN “MAJĄTEK ROGALIN” (CENTRAL WIELKOPOLSKA) ON THE BACKGROUND OF THE APPLIED MANAGEMENT WAY
}

\author{
Halina RatyńsKa, Ewa Wachowiak \\ H. Ratyńska, E. Wachowiak, Department of Botany, Institute of Environmental Biology, Kazimierz Wielki \\ University, al. Ossolińskich 12, 85-093 Bydgoszcz, Poland, e-mail: harat@ukw.edu.pl
}

(Received: January 30, 2014. Accepted: April 29, 2014)

\begin{abstract}
Aвstract. Nearly 200 hectares of grasslands in "Majątek Rogalin" (the Rogalin Estate) are situated on the Warta River floodplain, about 17 miles south of Poznań. Six positions of protected species have been found here. There are 10 regionally endangered species, while in the whole country - eight. Eighty-three plant communities belonging to 15 classes in phyto-sociological terms have been identified. Due to habitat conditions and manner of use, rushes of Phragmitetea rushes (18), Molinio-Arrhenatheretea grasslands (18), and Artemisietea vulgaris herbaceous species (12) are the most abundantly represented. Natural arrangements predominate (nearly $68 \%$ ), but semi-natural ones (19\%) are also numerous. A total of 30 phytocenons (over $37 \%$ ) are endangered. Following items are directly threatened with extinction (E): poplar riparian forest Populetum albae, herbaceous plants Veronico longifoliae-Euphorbietum lucidae, and cnidion meadow Violo stagninae-Molinietum caeruleae. Poplar riparian forest is very rare, and 15 associations are counted to rare ones. There have been 33 communities representative for 10 protected habitat types, including three - the priority ones. Considering the surface, following meadows dominate: Stellario palustris-Deschampsietum cespitosae and Rumici-Alopecuretum pratensis, in which 20-23 species have been reported. Cnidion meadows are much more abundant (from 29 to 42 species).

Natural and cultural values of the area were noticed a long time ago, which was reflected in numerous publications and proposals for protection: Rogalin Landscape Park, nature and landscape area "Rogalin Łęgi", Natura 2000 - Rogalin Warta River Valley, and together with the Wielkopolski National Park "The Special Protection Area - Rogalin Refuge". "Majątek Rogalin" implements the environmental programs, which means that farming is subordinated to nature conservation. Active protection and maintaining the traditional way of management contribute to the preservation of existing natural values.
\end{abstract}

KEY WORDS: vegetation, floodplain, Rogalin

\section{INTRODUCTION}

Natural and cultural values of the wide floodplain in the vicinity of Rogalin, in particular Rogalin Oaks - the largest stand of old oaks in Europe, have long been recognized. This was reflected in numerous publications and protection proposals (DENIsiuk \& Szoszkiewicz 1963, Denisiuk 1978, Kasprzak \& Pniewski 1978, Dąmbska 1981, Kaczmarek 1992, KRÓl et al. 1993, ŁAKOMIEC \& SZAFrańSKi 1997). As a result, the area was legally protected in 1997 as Rogalin Landscape Park, and it includes the nature and landscape area "Rogalin Łęgi" (WALCZAK et al. 2001). Oak trees growing singly or in groups have been protected as natural monuments since 1991. The natural qualities of the Park meet criteria of the EU nature refuges. Thus Natura 2000 - Rogalin Warta River Valley (PLH300012) and together with the Wielkopolski National Park "Special Protection Area - Rogalin Refuge" (PLB300010) could be created.

The research upon vegetation surrounding Rogalin consists of studies involving vegetation in oxbow lakes (WojtaszeK 1989). Many more studies refer to the vegetation cover of the Warta River valley (Szoszkiewicz \& Denisiuk 1965, Szoszkiewicz 1966, 1967, 1968, 1969, BORYSIAK 1994, RATYŃSKA \& SZWED 1999, RATYŃSKA 2001). So far, however, the area of "Majątek Rogalin" has not had any specific geo-bo- 
tanical recognition. This paper aims to fill this gap. Its purpose is to present the diversity of the flora and primarily vegetation associated with the flood terrace in "Majątek Rogalin". It results from both the natural conditions - periodic floods and management run for hundreds of years - mowing and grazing.

Due to historical and cultural values of the described area - painted, described, and photographed-clusters of old oak trees and the presence of numerous protected and extinction endangered species, as well as threatened and protected communities, it is extremely important to maintain the old way of management. It is also essential to restore the optimum habitat conditions for wetland birds (BEDNORZ 1976).

\section{GENERAL CHARACTERISTICS OF THE STUDY AREA}

The presented area is situated in the Central-European Lowlands province, sub-province of the Southern-Baltic Lake District, region of Great Valleys Belt, macro-region of Warta-Oder Rivers Ice Marginal Valley, and meso-region of Śrem Basin (KONDRACKI 1998). Administratively, it is a municipality Mosina with the proximity of Rogalin town near Poznań (Fig. 1). The Property is managed by the "Majactek Rogalin" Ltd., which has leased the farm since 1993, taken in 1945 from its rightful owners by the Agricultural Property Agency.

Relief is related to the Poznań phase of Baltic glaciation era. The Warta Valley was formed by converting the ice chute in the river valley to a width of a few kilometers, accompanied by terraces. The bottom of the Warta River valley is situated at an average height of 56.0 to $62.0 \mathrm{~m}$ a.s.l. The valley is almost flat, and the river has got the longitudinal direction (KonDRACKI 1998). The Warta River, when meandering, formed shallow, floodplain, and no-outflow ox- bow lakes of the arcuate shape. Construction of the dam reservoir in Jeziorsko, and its operation since 1992 (even before its complete investment), has changed the hydrological regime of the Warta River and helped to reduce the floods.

The Warta River valley consists principally of river sands and gravels from the above-floodplain terraces with layers of sandy silts. Poor quality soils were formed here, developed on mineral grounds or silt-peat soils underlain by loose sands. Over meadow floodplain terrace separated from the upland by a steep slope, there are forested dunes and farmlands associated with the higher-quality soils.

Average annual air temperature in Wielkopolska Lowland is about $7.5^{\circ} \mathrm{C}$ to $8.4^{\circ} \mathrm{C}$, the warmest month is July and the coldest January. Compared with other regions of Poland, there is the largest water deficit here. This is a result of relatively small precipitation (less than $500 \mathrm{~mm}$ near Śrem, on average). Warm but cloudy days prevail (Woś 1994).

According to the geo-botanical division of Poland, studied area belongs to the Wielkopolska-Kuyavian Land and Poznań-Gniezno District (Szafer 1972). According to the geo-botanical regionalization by Matuszkiewicz (1993), the analysed fragment of the Warta River valley is located within the Brandenburg-Wielkopolska division. It is the Central-Wielkopolska Land, Śrem District, sub-district of Warta River valley "Prosna Estuary - Poznań" (B.2.2.b).

The potential natural vegetation in the valley of the Warta River consists of the flooded riparian forests: Salicetum albae and Populetum albae. They are associated with the valleys of large and medium-sized rivers. Substrate is composed of fertile alluvial soils, mainly sandy, and periodically flooded. Riparian willow settles fragments of alluvium closer to the river bed and more frequently flooded. Riparian poplar can be found in the band closing the immersion zone. Phy-

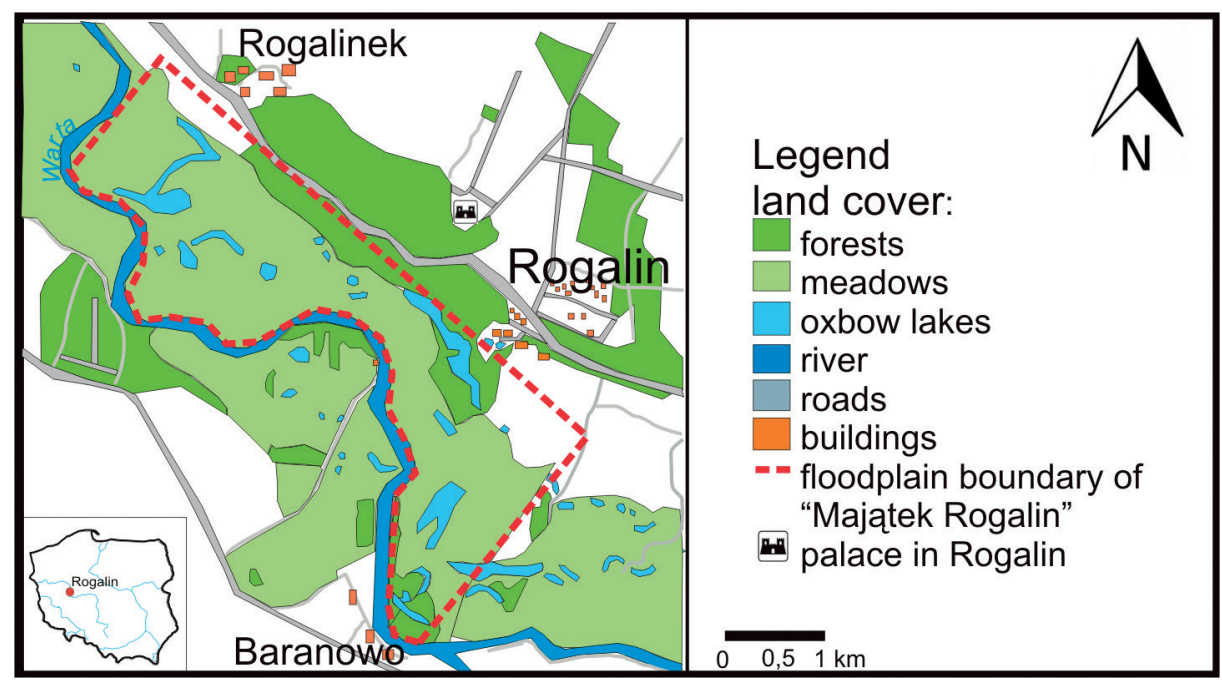

Fig. 1. Location of the study area 
tocenoses of willow and poplar forests are among the most damaged, both within the country and in the area concerned. Actual vegetation consists mainly of grasslands. On the wings of the valley, only small areas are covered with biotopes of fertile currant alder forest Carici elongatae-Alnetum. These are the marshy depressions with impeded outflow of water surrounding some of the oxbow lakes. Soil composed the low peat. Currently, the deforested places are dominated by sedges and rushes. In the neighbourhood, riparian ash-alder Fraxino-Alnetum develops on mineralized peat, and riparian elm-ash Querco-Ulmetum typicum develops on brown alluvial soils that are only episodically flooded. Only a small number of patches of these forest communities remained. They are replaced by grassland communities, herbaceous species, including a spectacular veil groups and bushes. Few dune elevations are a habitat of a potential mixed forest Querco roboris-Pinetum. The actual vegetation in such places is composed of less demanding groups of grasslands, including psammophilic meadows. Small arable lands are localized at the edge of the described area.

In recent years, a significant impact on the vegetation cover (in addition to the human economy) has been exerted by beavers contributing even to the extermination of woody species.

\section{MATERIAL AND METHODS}

Intensive field reconnaissance was conducted in 2004 and then in 2011 for the purpose of agri-environmental program. Collected materials were supplemented in the growing season 2013. For part of "Majątek Rogalin" located on the floodplain, a list of plant communities was drawn up. More prevalent phytocenons were documented using phyto-sociological records. A total of 36 records were made using a commonly accepted method by Braun-Blanquet with modifications by BARKMAN et al. (1964).

Systematics of plant communities is given after RATYŃSKA et al. (2010). According to the same authors, the emergency state and dissemination of phytocenons was assessed, as well as the classification in terms of their response to anthropogenic influences was performed. A list of the phyto-sociological units and types of habitats important for the European Community (Rozporządzenie... 2010), was also taken into account.

To assess the range of vegetation transformation, following indices of anthropogenic changes of vegetation were used (RATYŃSKA 2003): total synanthropization of vegetation index (Wcsr), that determined the percentage of domestic and anthropogenic phytocenons in a complete list of plant communities expressed as:

$$
W c s r=\frac{z n a+z a n}{z n p+z n a+z a n} \times 100 \%
$$

and index of anthropogenic communities proportion (War):

$$
\text { War }=\frac{z a n}{z n p+z n a+z a n} \times 100 \%
$$

where: $z n p$ - natural perdochoric communities that are displaced due to human activities, zna - natural auxochoric communities that enlarge their area due to human activities, zan - anthropogenic communities.

There has been no specific floristic recognition. However, the presence of threatened and endangered plants in the country and region attracted some attention (ZARZYCKI \& SzeląG 2006, JACKOWIAK et al. 2007). The basis of distinctions of plants being the subject to legal protection is the Regulation of the Minister of Environment of 20 January 2012 (Rozporządzenie... 2012).

To determine the differences between groups of plant communities, they were ordered according to gradients acting towards them, using the indirect ordination technique that allows for variable analysis based on mutual averaging algorithm such as DCA (Detrended Correspondence Analysis) (HiLl \& GAUCH 1980) in a two ordering axes system. Data from phyto-sociological records were summarized in tables, and then re-transformed from the scale of Braun-Blanquet coverage onto the numeric form according to the scheme proposed by van der MAAREL's (1979) in a following way: $\mathrm{r}-1,+-2,1-3,2 \mathrm{~m}-4$, $2 a-5,2 b-6,3-7,4-8,5-9$. Analyses concerning the cleanup methods were performed using MVSP software (Kovach 1999).

\section{RESULTS}

\section{SELECTED FLORISTIC ISSUES}

Besides clusters of old, monumental oaks, also numerous species of protected and endangered species are the floristic peculiarities of the analysed area. Positions of six species being under legal protection, including two under strict protection (Table 1, Fig. 2A, B), were found. Number of regionally endangered species is 10 . Only one of them has a category (EN - exposed), while six belong to vulnerable (VU). Nationally, eight species are endangered, most of category V - exposed. These plants, except from Myosurus minimus, Oenanthe fistulosa, and Convallaria maialis, are quite common, and their populations are abundant.

Moreover, among plant species that are rarely found on the studied area, there are Ranunculus flammula, Sanguisorba officinalis, and Wolffia arrhiza. 


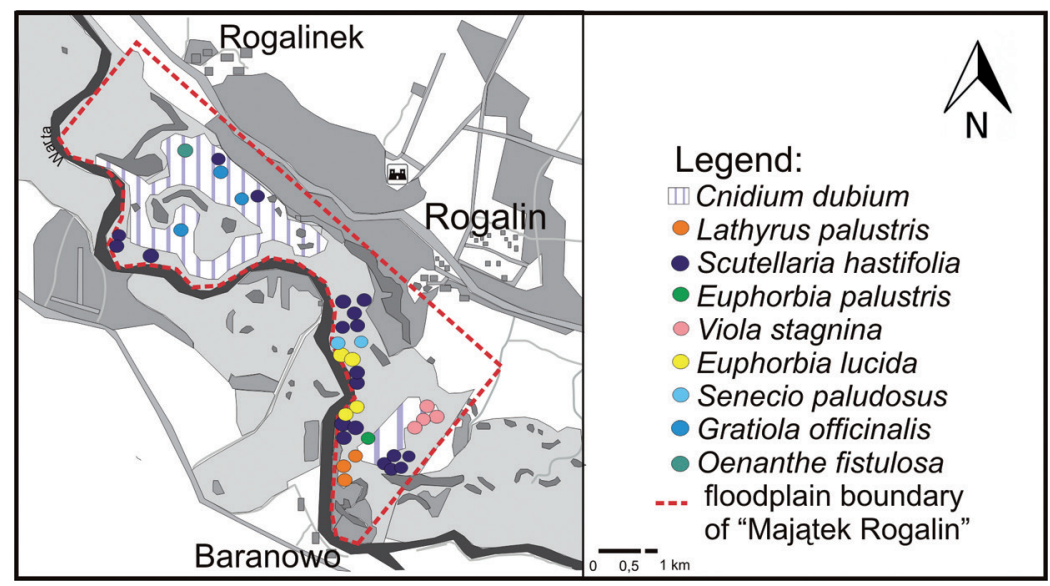

Fig. 2A. Distribution of rare and protected species of plants on the Warta River floodplain area in "Majątek Rogalin"

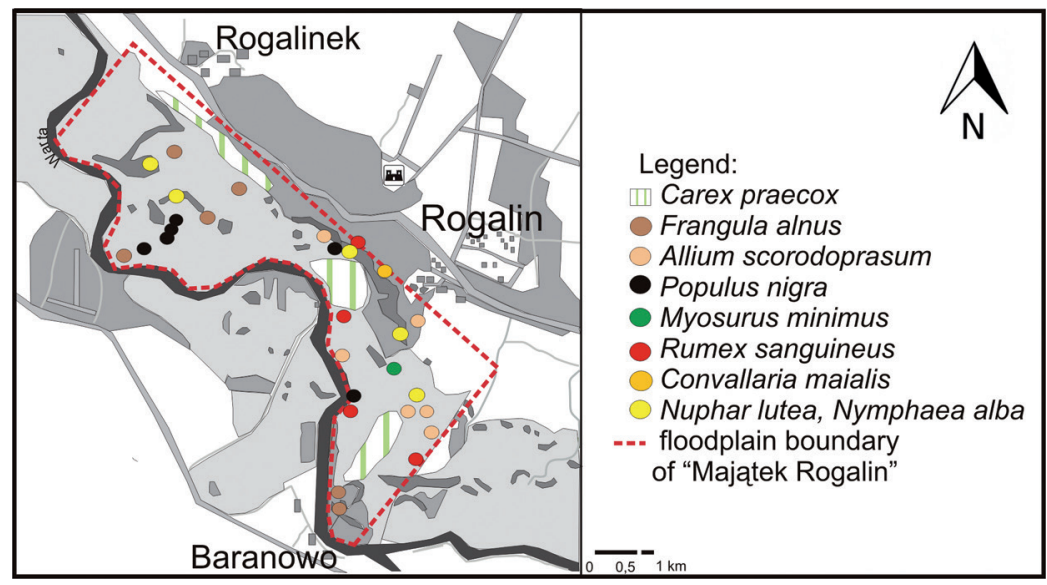

Fig. 2B. Distribution of rare and protected species of plants on the Warta River floodplain area in "Majątek Rogalin"

Table 1. List of protected and endangered species of plants

\begin{tabular}{lccc}
\hline \multicolumn{1}{c}{ Species } & $\begin{array}{c}\text { Species } \\
\text { protection }\end{array}$ & $\begin{array}{c}\text { Regional } \\
\text { threat in } \\
\text { Wielkopolska }\end{array}$ & $\begin{array}{c}\text { Endangered } \\
\text { species in } \\
\text { Poland }\end{array}$ \\
\hline Allium scorodoprasum & - & - & $\mathrm{V}$ \\
Cardamine parviflora & - & EN & - \\
Carex praecox & - & - & $\mathrm{V}$ \\
Cnidium dubium & - & LC & V \\
Convallaria majalis & $*$ & - & - \\
Euphorbia lucida & - & VU & - \\
Euphorbia palustris & - & LC & V \\
Frangula alnus & $*$ & - & - \\
Gratiola officinalis & $* *$ & VU & - \\
Lathyrus palustris & - & - & V \\
Myosurus minimus & - & - & V \\
Nuphar lutea & $*$ & - & - \\
Nymphaea alba & $*$ & - & - \\
Oenanthe fistulosa & - & VU & - \\
Populus nigra & - & LC & - \\
Rumex sanguineus & - & VU & - \\
Scutellaria hastifolia & - & - & V \\
Senecio paludosus & - & VU & - \\
Viola stagnina & $* *$ & VU & E \\
\hline
\end{tabular}

*Partial protection of species; **Strict protection of species; EN, $\mathrm{E}$ - endangered; LC - least concern; VU, V - vulnerable.

\section{CHARACTERISTICS OF VEGETATION SYNTAXONOMY}

Eighty-three patches of phytocenons were identified in the study area (Table 3). They belong to 15 classes in phyto-sociological terms. Due to the type of habitat and the way of use, groups of Phragmitetea rush (18), grasslands with Molinio-Arrhenatheretea (18), as well as herbaceous and ruderal with Artemisietea vulgaris (12) entering the non-grazed and not mown meadows and pastures and associated roads, especially at the edge of floodplain, are the most abundantly represented.

In the area Radzewice-Rogalinek, WoJTASzeK (1989) reports, besides Hottonietum palustris, Sagittario-Sparganietum emersi, and Ceratophylletum demersi phytocenoses found within "Majątek Rogalin", also following riparian and rush associations in oxbow lakes: Potametum lucentis, Potametum perfoliati, and Equisetetum limosi. 


\section{AUTOGENIC AND ANTHROPOGENIC COMMUNITIES}

Considering the syngenesis, the natural groups predominate, mainly auxochoric ones (Fig. 3). These are water and rush communities, coastal therophytes, herbaceous species, scrubs, and forests. Together, they constitute nearly $68 \%$. Semi-natural communities mainly grasslands (19\%) dominating in terms of occupied area - are also numerous. Ruderal phytocenons present mainly along the roads, share a little over $6 \%$ of all groups; they occupy a small acreage. A small percentage of xenospontaneous associations is interesting, although their number and occupied area slowly increase. Due to the fact that the fields are present only on the outskirts of the studied area, the segetal communities are very poorly represented and usually vestigial. They accompany small separated crop plots: rye and potatoes.

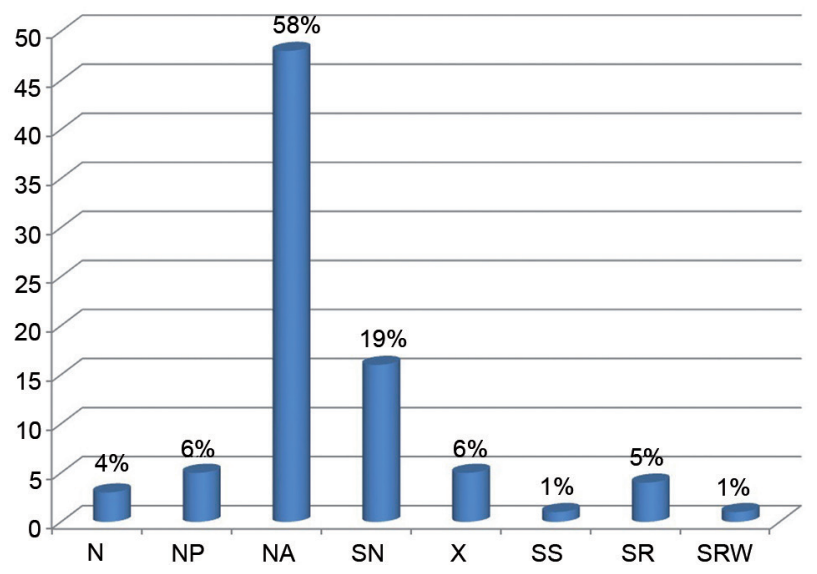

Fig. 3. Share of autogenic and anthropogenic communities on the vegetation of the Warta River floodplain area in "Majątek Rogalin"

\section{THREATENED AND RARE COMMUNITIES}

Within the floodplain of "Majątek Rogalin", belts of three patches of associations directly threatened with extinction, the category $\mathrm{E}$ in the country, are found. It is a fragmentary preserved poplar riparian forest Populetum albae, meadow herbaceous species Veronica longifoliae-Euphorbietum lucidae, and cnidion meadow Violo stagninae-Molinietum caeruleae. In addition, 13 phytocenons are exposed $(\mathrm{V})$, and 15 is of category I - with unspecified threat. A total of 30 patches of threatened communities were found, which is more than $37 \%$.

Most of the groups represent frequent and common communities. Poplar riparian forest Populetum albae is very rare and 15 phytocenons belong to the rare ones (Table 2 ).

\section{PROTECTED TYPES OF HABITATS}

There have been 33 plant communities representative for 10 protected habitat types, including three priority categories (Table 3 ).

Code Name of the natural habitat type

1340 Inland salt meadows, pastures and rushes (Glauco-Puccinietalia part - inland communities)

2330 Inland dunes with open Corynephorus and Agrostis grasslands

3130 Oligotrophic to mesotrophic standing waters with vegetation of the Littorelletea uniflorae and/or of the Isoëto-Nanojuncetea

3150 Natural eutrophic lakes with Magnopotamion or Hydrocharition - type vegetation

3270 Rivers with muddy banks with Chenopodion rubri p.p. and Bidention p.p. vegetation

6120 Xeric sand calcareous grasslands

Table 2. Comparison of the number of species and cover factors in chosen groups of plant communities

\begin{tabular}{|c|c|c|c|c|c|c|}
\hline & Rushes & $\begin{array}{c}\text { Herbaceous } \\
\text { species }\end{array}$ & $\begin{array}{c}\text { Meadows, } \\
\text { pastures }\end{array}$ & $\begin{array}{l}\text { Cnidion } \\
\text { meadows } \\
\text { (Violo-Molinie- } \\
\text { tum caeruleae) }\end{array}$ & $\begin{array}{c}\text { Grassland } \\
\text { communities } \\
\text { and ruderal } \\
\text { herbaceous } \\
\text { plants }\end{array}$ & $\begin{array}{c}\text { Communities } \\
\text { of treaded } \\
\text { places }\end{array}$ \\
\hline Number of relevés in the field & 5 & 10 & 8 & 6 & 5 & 2 \\
\hline Average number of species per relevé & 11 & 14 & 23 & 35 & 20 & 12 \\
\hline \multirow[t]{2}{*}{ Number of species in the table } & 36 & 53 & 92 & 89 & 68 & 22 \\
\hline & \multicolumn{6}{|c|}{ Constanty and coverage coefficient } \\
\hline Phragmitetea & $11^{8868}$ & $4^{381}$ & $6^{70}$ & $5^{15}$ & $1^{2}$ & $1^{5}$ \\
\hline Bidentetea tripartiti & $2^{35,6}$ & - & $2^{65}$ & $2^{256,6}$ & $1^{2}$ & - \\
\hline Artemisietea & $5^{112}$ & $17^{8760}$ & $16^{2028}$ & $15^{4691,6}$ & $9^{574}$ & $6^{900}$ \\
\hline Molinio-Arrhenatheretea & $13^{930}$ & 223839 & $45^{10612,5}$ & $37^{12098,3}$ & $20^{1446,6}$ & $9^{1160}$ \\
\hline Koelerio-Corynephoretea & - & $1^{1}$ & $1^{1,25}$ & $8^{471,6}$ & $12^{2935}$ & - \\
\hline Polygono-Poetea annuae & - & - & $1^{1,25}$ & - & $2^{352}$ & $3^{8635}$ \\
\hline Festuco-Brometea and Trifolio-Geranietea & - & - & $2^{720}$ & $8^{1223,3}$ & $6^{770}$ & - \\
\hline Stellarietea mediae & $3^{104}$ & $3^{577}$ & $7^{133,75}$ & $5^{11,6}$ & $7^{464}$ & $3^{15}$ \\
\hline Others & $1^{8}$ & $6^{587}$ & $12^{480}$ & $9^{2931,6}$ & $10^{2524}$ & - \\
\hline
\end{tabular}


6430 Hydrophilous tall herb fringe communities of plains and of the montane to alpine levels

6440 Alluvial meadows of river valleys of the Cnidion dubii

91E0 Alluvial forests with Alnus glutinosa and Fraxinus excelsior (Alno-Padion, Alnion incanae, Salicion albae)

91F0 Riparian mixed forests of Quercus robur, Ulmus laevis and Ulmus minor, Fraxinus excelsior or Fraxinus angustifolia, along the great rivers (Ulmenion minoris)

Within the floodplain, due to the occupied area and number of typical communities, natural eutrophic lakes with Magnopotamion or Hydrocharition (3150) and Hydrophilous tall herb fringe communities of plains and of the montane to alpine levels (6430) deserve a special attention. Share of the latter increases resulting from the liquidation of some patches of riparian communities by beavers. Cnidion meadows (6440) are in the form of generally small, scattered patches, like phytocenoses of open grasslands. Riparian forests of various types (91E0, 91F0) are preserved only in fragments and show signs of degeneration. Other communities, although important from the biocenosis point of view, are developed on small areas.

The remains of xerothermic meadows (6210) are present within "Majątek Rogalin" at the edge of the Warta River valley. However, due to the far-reaching process of secondary succession and a small area, this hull-shaped community was not included in the list of protected habitat types. Distribution of habitat types, that cover larger and constant areas, is shown on Figure 4.

\section{INDICATORS OF ANTHROPOGENIC CHANGES AT PLANTS}

Primarily pasture-grazing management is performed on the floodplain. Also natural wet biotopes - the Warta River oxbow lakes and the remains of riparian forests and riverine wicker - are present.
Thus, within the vegetation, there is a relatively small share of highly synanthropic communities: ruderal and segetal ones. On the other hand, natural perdochoric groups also constitute low percentage of small quantities and surface. As a result, the total vegetation synanthropisation rate is very high amounting to $87.1 \%$. In turn, the participation rate of anthropogenic communities in vegetation has relatively little value: $40.0 \%$.

\section{REVIEW OF SELECTED PLANT COMMUNITIES}

Detailed study referred mainly to grasslands $\mathrm{Mo-}$ linio-Arrhenatheretea, rush of Phragmitetea, and lawns with Koelerio-Corynephoretea, as well as communities with Artemisietea that evolved after giving up the pasture-grazing management. In total, 28 species were documented using phyto-sociological records.

\section{GRASSLAND COMMUNITIES \\ OF MOLINIO-ARRHENATHERETEA CLASS}

Grassland vegetation dominates in terms of occupied area in the Warta River valley and is of a great economic importance. Within the "Majątek Rogalin", 13 plant communities with Molinio-Arrhenatheretea were identified and nine of them were phyto-sociologically documented. They are floristically quite abundant; from 20 to 26 species were recorded with an average of 23. Coverage of herbaceous plants is very large and a moss layer developed only sometimes, not exceeding 5\%. Exceptions are patches of cnidion meadow, where mosses sometimes reach up to $40 \%$ coverage. This community is also floristically the most abundant. In the records, there are from 29 to 42 with an average of 31 plant species, while 89 in the entire table.

Although Violo stagninae-Molinietum caeruleae phytocenoses are rare in the study area and occur only in the form of small, scattered patches, usually on slightly elevated places in the complex of foxtail grass meadows, thus they have no economic significance, they are very important for the biocenotic reasons. In addition to species abundance, they are characterised

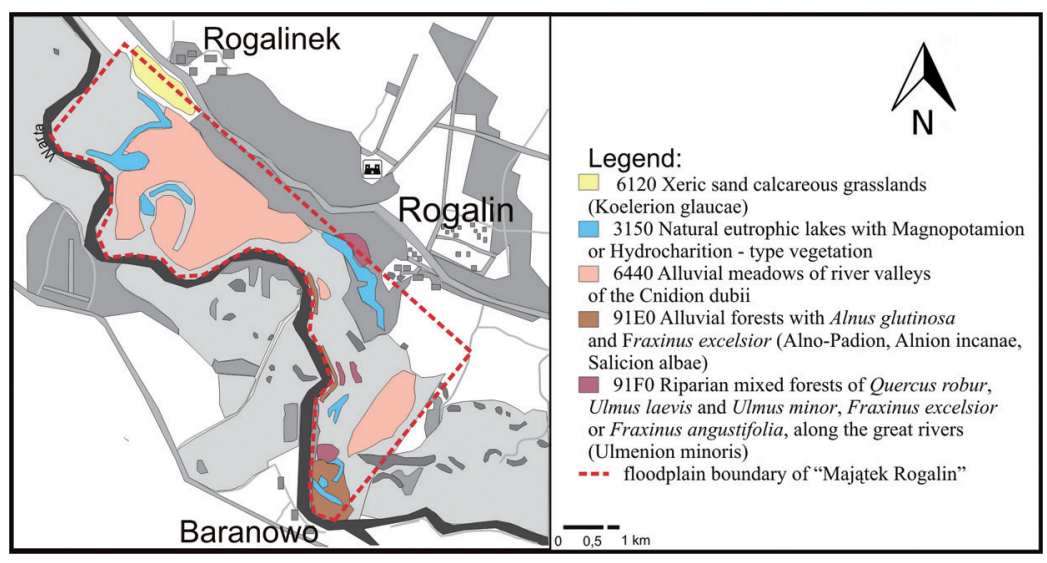

Fig. 4. Distribution of chosen protected habitats on the vegetation of the Warta River floodplain area in "Majątek Rogalin" 
Table 3. List of plant communities of the Warta River floodplain area in "Majątek Rogalin" and its characteristics

\begin{tabular}{cccc}
\hline \multirow{2}{*}{ Syntaxon } & Categories & Syngene- & Frequency \\
92/43/EEC \\
Directive
\end{tabular}

Scrub and forest communities

Cl. Salicetea purpureae Moor 1958

O. Salicetalia purpureae Moor 1958

All. Salicion albae Soó 1930 em. Moor 1958

1. Salicetum albae Issler 1926

2. Populetum albae Br.-Bl. 1931

3. Salicetum triandro-viminalis Lohmeyer 1952

Cl. Querco-Fagetea Br.-Bl. et Vlieger 1937

O. Fagetalia sylvaticae Pawłowski in Pawłowski et al. 1928

All. Alnion incanae Pawłowski in Pawłowski et al. 1928

4. Fraxino-Alnetum W. Mat. 1952

5. Querco-Ulmetum Issler 1924

Cl. Rhamno-Prunetea Rivas-Goday et Borja Carbonell 1961 ex R. Tx. 1962

O. Prunetalia spinosae R. Tx.1952

All. Urtico-Crataegion Pass. in Pass. et Hofmann 1968

6. Euonymo-Prunetum spinosae (Hueck 1931) Pass. in Pass. et Hofmann 1968

7. Euonymo-Cornetum sanguinei Pass. in Pass. et Hofmann 1968

Water and murshy communities

Cl. Lemnetea minoris (R. Tx. 1955) de Bolós et Masclans 1955

O. Lemnetalia minoris (R. Tx. 1955) de Bolós et Masclans 1955

All. Lemnion minoris (R. Tx. 1955) de Bolós et Masclans 1955

8. Lemnetum gibbae (Bennema et al. 1943) Miyawaki et J. Tx. 1960

9. Wolffietum arrhizae (Bennema et al. 1943) Miyawaki et J. Tx. 1960

$\begin{array}{cccc}\text { V } & \text { NP } & \text { R } & * 91 E 0 \\ \text { E } & \text { NP } & \text { RR } & * 91 E 0 \\ - & \text { NA } & \text { C } & \end{array}$

Ch. Ass.: Wolffia arrhiza (dom./kodom.)

10. Lemno-Spirodeletum polyrhizae W. Koch 1954 ex Th. Müller et Görs 1960

11. Lemnetum minoris Soó 1927

12. Lemnetum trisulcae (Kelhofer 1915) R. Knapp et Stoffers 1962

Cl. Potametea Klika in Klika et Novák 1941

O. Potametalia W. Koch 1926

All. Potamion pectinati (W. Koch 1926) Görs 1977

13. Potametum pectinati (Hueck 1931) Carstensen 1955

14. Elodeetum canadensis Eggler 1933

15. Ceratophylletum demersi Hild 1956

16. Ranunculetum circinati Sauer 1937

I

$\mathrm{V}$

V

$\mathrm{N}$

NP

C

C

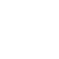


29. Caricetum gracilis Almquist 1929

30. Caricetum vulpinae (Soó 1927) Nowiński 1928

NA

$\mathrm{P}$

31. Caricetum vesicariae Br.-Bl. et Denis 1926

\section{$\mathrm{V}$}

O. Nasturtio-Glycerietalia Pignatti 1953

All. Oenanthion aquaticae Hejný ex Neuhäusl 1959

32. Oenantho aquaticae-Rorippetum amphibiae Lohmeyer 1950

33. Glycerio-Oenanthetum aquaticae (Eggler 1933) Hejný 1948 em. 1978

34. Sagittario-Sparganietum emersi R. Tx. 1953

35. Butometum umbellati Konczak 1968

36. Eleocharitetum palustris Schennikov 1919 ex Ubrizsy 1948

All. Phalaridion Kopecký 1961

37. Phalaridetum arundinaceae Libbert 1931

Short-lived communities of muddy banks and shores and periodically flooded depressions

Cl. Isoëto durieui-Juncetea bufonii (Br.-Bl. et R. Tx. 1943 ex Westhoff et al. 1946) Rivas-Martinez 1988

O. Nanocyperetalia Klika 1935

All. Elatino-Eleocharition ovatae (Pietsch et Müller-Stoll 1968) Pietsch 1973

38. Cypero fusci-Limoselletum Oberd. 1957 ex Korneck 1960

V

All. Radiolion linoidis (Rivas-Goday 1961) Pietsch 1973

39. Juncetum bufonii Felföldy 1942

Cl. Bidentetea tripartitae R. Tx. et al. in R. Tx. 1950

O. Bidentetalia tripartitae Br.-Bl. et R. Tx. 1943

All. Bidention tripartitae Nordhagen 1940 em. R. Tx. in Poli et J. Tx. 1960

40. Bidenti-Polygonetum hydropiperis (Miljan 1933) Lohmeyer in R. Tx. 1950 nom. invers.

41. Bidenti-Rumicetum maritimi (Miljan 1933) R. Tx. 1979

All. Chenopodion glauci (R. Tx. in Poli et J. Tx. 1960) Hejný 1974

42. Bidenti-Atriplicetum prostratae Poli et J. Tx. 1960 corr. Gutermann et Mucina 1993

43. Chenopodio rubri-Polygonetum brittingeri Lohmeyer 1950 nom. invers.

44. Chenopodietum rubri Timár 1947

Xerothermic grasslands and herbaceous vegetation of shrubs in forest edge

Cl. Koelerio-Corynephoretea Klika in Klika et Novák 1941

O. Corynephoretalia canescentis Klika 1934

All. Thero-Airion R. Tx. 1951 ex Oberd. 1957

45. Sclerantho polycarpi-Herniarietum glabrae Głowacki 1988 ex Brzeg et M. Wojterska 2001

46. Armerio elongatae-Festucetum ovinae R. Knapp 1944 ex Celiński 1953

All. Koelerion glaucae Volk 1931

47. Corynephoro-Silenetum tataricae Libbert 1931

Cl. Festuco-Brometea Br.-Bl. et R. Tx. 1943

48. fragmentarily developed communities

Cl. Trifolio-Geranietea sanguinei Th. Müller 1962

O. Origanetalia vulgaris Th. Müller 1962

All. Trifolion medii Th. Müller 1962

49. Trifolio medii-Agrimonietum Th. Müller 1962

50. Agrimonio-Vicietum cassubicae Pass. 1967 nom. invers.

Grassland communities, species-rich Nardus grasslands and heaths with Calluna

Cl. Molinio-Arrhenatheretea R. Tx. 1937 em. 1970

51. Anthoxanthum odoratum Community

52. Phleum pratense Community

$\begin{array}{lll}- & \text { SN } & \text { C } \\ - & \text { SN } & \text { C }\end{array}$

O. Molinietalia W. Koch 1926

All. Filipendulion ulmariae (Duvigneaud 1946) Segal 1966 ex Lohmeyer in Oberd. et al. 1967

53. Scutellario hastifoliae-Veronicetum longifoliae Walther 1955 nom. invers.

54. Lysimachio vulgaris-Filipenduletum Bal.-Tulačková 1978

55. Veronico longifoliae-Euphorbietum lucidae Bal.-Tulačková et Knežević 1975 
All. Calthion R. Tx. 1937

57. Poo palustris-Lathyretum palustris Walther in R. Tx. 1955 ex Walther 1977

$\begin{array}{lll}\text { V } & \text { SN } & \text { R } \\ - & \text { SN } & \text { C } \\ - & \text { SN } & \text { P } \\ & & \\ \text { E } & \text { SN } & \text { R }\end{array}$

\section{R}

58. Ranunculo repentis-Alopecuretum pratensis Krisch 1974

59. Stellario palustris-Deschampsietum cespitosae Freitag 1957

All. Molinion W. Koch 1926 (Syn.: Cnidion dubii Bal.-Tulačková 1966 sensu auct. p.p.)

60. Violo stagninae-Molinietum caeruleae Pass. 1955

E

$\mathrm{C}$

$P$

O. Trifolio repentis-Plantaginetalia majoris (R. Tx. et Preising in R. Tx. 1950 em. Sissingh 1969) Brzeg 1991 ex Balcerkiewicz et Pawlak 2001

All. Cynosurion R. Tx. 1947

61. Lolio perennis-Cynosuretum cristati R. Tx. 1937

62. Lolio-Plantaginetum Beger $1932 \mathrm{em}$. Sissingh 1969

63. Juncetum macri (Diemont et al. 1940) R. Tx. 1950

All. Potentillion anserinae R. Tx. 1947

64. Potentillo-Festucetum arundinaceae (R. Tx. 1937) Nordhagen 1940 nom. invers.

65. Ranunculo repentis-Alopecuretum geniculati R. Tx. 1937 em. 1950

66. Ranunculetum repentis R. Knapp 1946 ex Oberd. 1957

67. Potentilletum anserinae Rapaics 1927 em. Pass. 1964

68. Potentilletum reptantis Eliáš 1974 (Syn.: Prunello-Potentilletum reptantis Eliáš 1978)

Nitrophilous herbaceous vegetation

Cl. Artemisietea vulgaris Lohmeyer et al. in R. Tx. 1950

O. Convolvuletalia sepium R. Tx. 1950 ex Lohmeyer 1953 em. Oberd. in Oberd. et al. 1967

All. Senecionion fluviatilis R. Tx. 1950 ex Lohmeyer 1953

69. Urtico-Convolvuletum sepium Görs et Th. Müller 1969

70. Convolvulo sepium-Cuscutetum europaeae R. Tx. 1947 ex Lohmeyer 1953

71. Calystegio-Asteretum lanceolati Holzner et al. ex Pass. 1993

72. Fallopio-Humuletum lupuli Brzeg 1989 ex Brzeg et M. Wojterska 2001

73. Carduo crispi-Rubetum caesii Brzeg in Brzeg et M. Wojterska 2001

74. Sicyo-Echinocystietum lobatae Fijałkowski 1978 ex Brzeg et M. Wojterska 2001

All. Galio-Alliarion (Oberd. 1962) Lohmeyer et Oberd. in Oberd. et al. 1967

75. Alliario-Chaerophylletum temuli Lohmeyer 1949

76. Myosotido sparsiflorae-Alliarietum petiolatae Gutte 1973

O. Onopordetalia acanthii Br.-Bl. et R. Tx. 1943

All. Onopordion acanthii Br.-Bl. 1926 ex Br.-Bl. et al. 1936

77. Tanaceto-Artemisietum Sissingh 1950

All. Convolvulo-Agropyrion Görs 1966

78. Rubo caesii-Calamagrostietum epigeji Coste 1985

79. Convolvulo-Brometum inermis Eliáš 1979

80. Saponaria officinalis sensu auct. nom. inval.

Ruderal and segetal short-lived communities

Cl. Stellarietea mediae R. Tx. et al. in R. Tx. 1950

O. Aperetalia spicae-venti J. et R. Tx. in Malato-Beliz et al. 1960 em. Hüppe et Hofmeister 1990

All. Scleranthion annui (Kruseman et Vlieger 1939) Sissingh in Westhoff et al. 1946

81. Sclerantho-Arnoseridetum minimae R. Tx. 1937

Cl. Polygono-Poetea annuae Rivas-Martinez 1975

O. Polygono arenastri-Poetalia annuae R. Tx. in Géhu et al. 1972 corr. Rivas-Martinez et al. 1991

All. Polygono-Coronopodion squamati Sissingh 1969

82. Poetum annuae Felföldy 1942

83. Matricario matricarioidis-Polygonetum arenastri Th. Müller in Oberd. 1971

$\begin{array}{lcll}- & \text { NA } & \text { C } & 6430 \\ \text { I } & \text { NA } & \text { R } & 6430 \\ - & \text { X } & \text { C } & \\ - & \text { NA } & \text { P } & 6430 \\ - & \text { NA } & \text { C } & 6430 \\ \text { O } & \text { X } & \text { C } & \\ & & & \\ - & \text { NA } & \text { P } & \\ - & \text { NA } & \text { C } & \\ & & & \\ - & \text { SR } & \text { P } & \\ & & & \\ \text { O } & \text { SR } & \text { C } & \\ \text { O } & \text { SR } & \text { C } & \\ - & \text { SR } & \text { C }\end{array}$

V SS C

Categories of threat

E - endangered community, V - vulnerable, I - undetermined threat, “-” - not threatened O - expansion.

Syngenesis: N - natural community, NP - natural perdochoric community, NA - natural auksochoric, SN - seminatural community, $\mathrm{X}$ - xenospontaneous community, SS - synanthropic segetal communities, SR - synanthropic ruderal communities, SRW - specialized synanthropic ruderal communities.

Frequency: P - common, C - frequent, R - rare, RR - very rare, 92/43/EEC Directive - Council Directive 92/43/EEC of 21 May 1992 on the conservation of natural habitats and of wild fauna and flora, Poradnik Ochrony Siedlisk i Gatunków (HERBICH 2004, RATYŃSKA et al. 2010). 
by the presence of many protected and endangered species; they also represent a protected habitat type. In addition to diagnostic taxa, characteristic Molinio-Arrhenatheretea were reported in numerous patches and with high degrees of stability and coverage. There are always the thermophilic species - typical for xerothermic and sand lawns as well as thermophilic edges. Artemisietea edificators are relatively frequent. Only few communities with Phragmitetea, Alnetea glutinosae, and Bidentetea tripartiti were recorded in the wettest habitats.

Patches of Stellario palustris-Deschampsietum cespitosae are the prevalent. This group, floristically the poorest, is distinguished by the dominance of daredevil turf and represents the neglected meadows and extensive pastures. A significant share of pasture species with Trifolio repentis-Plantaginetalia majoris is characteristic. Among other grassland communities, Artemisietea and Stellarietea mediae are negatively distinguished by the absence of edificators.

Ranunculo repentis-Alopecuretum pratensis is very valuable community due to its high feed values. Its phytocenoses are dominant in the Warta River valley. In the upper layer of the sword, meadow foxtail prevails, and small perennials spread lower.

Low grazing pastures are also frequent, although they occupy a small area: Potentilletum anserinae with domination of common silverweed, Ranunculo repentis-Alopecuretum geniculati with a large share of creeping bentgrass, that is distinguished by the largest group of edificators of Trifolio repentis-Plantaginetalia majoris, floristically the richest (26 species) community of Potentillo-Festucetum arundinaceae with massive participation and reed fescue, as well as Lolio-Cynosuretum community, where white clover is of the largest percentage.

The pasture lawns also include patches of Ranunculetum repentis, in which common couch grass dominates. This community is the least abundant in characteristic Molinio-Arrhenatheretea within the studied groups of grasslands. They are distinguished by a large group of Artemisietea edificators and trees and shrubs seedlings.

In phytocenoses of meadows with in-sown timothy, species of dry habitats such as common bent grass, St. John's wort, and pink polka dots are quite numerous.

Meadow-pasture vegetation is mainly related to the dynamic circle of riparian willow. Only groups with common couch grass Elymus repens and Phleum pratense as well as Anthoxanthum odoratum are typical for riparian poplar, or are degenerate forms of desiccated meadows and foxtail grasslands.

\section{RUSH COMMUNITIES}

Rushes occupy a substantial area and develop within the former oxbow lakes, now without water or only periodically flooded. They are also present in the form of a narrow band on the outskirts of oxbow lakes. These are non-forest habitats or wetter riparian willow habitats. Patches of 18 communities were found, and five of the most common ones were phyto-sociologically documented.

Among communities with Phragmitetea, patches with manna gizzard, reed canary grass and sedge pointed, sometimes with mud sedge have some economic importance. They tend to be mown and hay collected, due to the small feed value, is usually used as litter.

Within the analysed groups, phytocenoses with Glyceria maxima are floristically the poorest. Nearly $100 \%$ of coverage of relatively high, dense rush of manna mielec reduces the occurrence of other plants. Furthermore, habitats dominated by the analysed association are very humid.

Patches with Carex acutiformis and C. riparia are equally moist and almost as poor. Meadow species have negligible share and besides the rush ones, herbaceous species with Artemisietea are present in Caricetum acutiformis.

Phalaris arundinacea group is much more abundant. Although accompanying plants do not achieve greater coverage, they are two times more numerous than in the case of the earlier discussed community. The largest number of Molinio-Arrhenetheretea edificators is found within them.

The largest number of species were found within the dried rushes Caricetum gracilis. Besides single Phragmitetea edificators, dicotyledonous plants of grassland have significant contribution.

\section{HERBACEOUS COMMUNITIES}

Although herbaceous communities are represented in large numbers, their patches do not cover a larger area. In all phytocenoses, the herbaceous cover layer is very large. They belong to Molinio-Arrhenetheretea (4 phyto-sociologically documented communities) and Artemisietea vulgaris (8 groups, including 6 phyto-sociologically documented ones), while the latter were more frequently observed. Analysed phytocenons are formed on the banks of water reservoirs, edges of trees and bushes. The humidity of habitats is evidenced by the presence of characteristic Phragmitetea in most of the patches. Giving up or reduction of grazing and mowing helps to increase their surface.

Herbaceous meadows are not floristically too abundant (13-15 taxa) and usually a single species dominates. There are patches with: Achillea ptarmica, Scutellario hastifoliae-Veronicetum longifoliae, Veronico longifoliae-Euphorbietum lucidae, and Achilleo salicifoliae-Cuscutetum lupuliformis. Besides participation of numerous Molinio-Arrhenatheretea edificators. They are distinguished by the lack of herbaceous species with Artemisietea. 
The meadow species were observed in nitrophilous herbaceous vegetation with Artemisietea, only as one or none at all. In particular documents, from 9 to 17 taxa, with average of 13, were recorded. Species with Artemisietea, especially with Convolvuletalia sepium, are numerous and occur in high coverage. Within the analysed group, both communities dominated by perennials: Urtico-Convolvuletum sepium, Carduo crispi-Rubetum caesii, Cirsium arvense, and those built mainly from plants with short life cycles: Myosotido sparsiflorae-Alliarietum petiolatae, Alliario-Chaerophylletum temuli, are found.

Above discussed groups are substitute mainly for riparian willow, while only patches with garlic mustard, rough chervil, rarely with European dewberry appear on riparian poplar habitat.

\section{GRASSLAND COMMUNITIES AND RUDERAL HERBACEOUS PLANTS}

Grassland vegetation in Warta River valley is represented by three phyto-sociologically documented communities. A specific psammophilic lawn with prevailing Tatarian catchfly occurring only in the valleys of large rivers in places elevated above the level of average floods, is Corynephoro-Silenetum tataricae. In this rather abundant community, besides typical Koelerio-Corynephoretea, there are many other numerous plants of mesophilic habitats.

However, floristically the most abundant (as many as 28 species) is Armerio elongatae-Festucetum ovinae grass. It is characterised by a very large share of characteristic Molinio-Arrhenatheretea, especially typical of pasture, as well as helio and thermophilic plants with Koelerio-Corynephoretea, Trifolio Geranietea sanguinei, and Festuco-Brometea.

The grass with domination of Herniaria glabra (Sclerantho polycarpia-Herniarietum glabrae) is distinguished by almost complete lack of meadow plants. It grows on sandy habitats in treaded places.

Ruderal herbaceous plants of thermophilic nature with Artemisietea are represented by patches of four associations, including two documented by phyto-sociological records. Phytocenoses with wood smallreed Rubo caesii-Calamagrostietum epigeji are present on the border of grassland and ruderal groups. There are numerous species of lawns and thermophilic edges, as well as grasslands. Among accompanying plants, the most abundant one was characteristic Stellarietea mediae. A total of 26 species were found.

Phytocenosis with common soapwort is floristically much poorer, because it includes only 14 species. No characteristic Koelerio-Corynephoretea is surprising, while there are many Artemisietea edificators.

Grassland and ruderal communities are associated with a dynamic circle of poplar riparian forest or local dunes.

\section{COMMUNITIES OF TREADED PLACES (TREADED VEGETATION)}

Treaded places within the alluvia of the Warta River are represented by patches of Matricario matricarioidis-Polygonetum arenastri and Poetum annuae. They were observed on small areas, on roads designed for hay transport, and fishing paths. The plant height in general does not exceed a few centimeters. Most species are resistant to mechanical destruction: treading and riding. Very compact ground is a negative feature, because it reduces water infiltration. Therefore, the number of recorded species is the smallest within the analysed groups (from 8 to 16). Nevertheless, the herbaceous plant cover is high (from 70 to 95\%) and that of moss layer - negligible.

Patch with Polygonum aviculare s.l. is floristically the most abundant. Besides proportion of Polygono-Poetea annuae edificators, it is characterised by the presence of characteristic Artemisietea and Molinio-Arrhenatheretea.

The lowest number of species was found in phytocenosis with Poa annua. Large coverage of annual bluegrass and specific and extremely difficult conditions for plant life make that only a few Polygono-Poetea annuae edificators were recorded and species with Molinio-Arrhenatheretea that are the most resistant to treading.

The studied communities are replacement for riparian willow.

\section{DISCUSSION}

For hundreds of years, the Warta River valley has been used for agricultural purposes. Several hay cuts have been harvested from the floodplains which served as pasture for cattle and other animals. The testimony of the method development are characteristic silhouette of single old oak trees growing from the beginning in the open space. They were immortalized in numerous paintings (by Leon Wyczółkowski, Michał Gorstkin-Wywiórski) and repeatedly photographed (e.g. Zygmunt Pniewski, Maciej Fiszer).

In 1996-2003, grazing on the Łęgi Rogalińskie area was not carried out. In this period, succession by nitrophilous herbaceous species in the direction of forests, was present. Herbaceous and scrub plants entering the abandoned grasslands are much poorer than the extensively used meadows (Jongman 1996), which is confirmed by the results of own research (Table 2). Giving up mowing and grazing results in the deposition of large amounts of non-decomposed organic matter, and in consequence, entering the nitrophilous plants such as Urtica dioica, Rumex obtusifolius, Cirsium arvense, C. oleraceum, Elymus repens, and Galium aparine (BARABASZ 1997). Most of these species are also in the expansion on the meadows of the Ojcowski National Park (Michalik 1990, Kornaś \& 
Dubiel 1991) and belong to the widespread ones in the catchment area of the Główna River (RATYŃSKA 2003). Currently (since 2004), in Warta River valley, grazing (cows first, then sheep) and regular mowing takes place. Bringing animals on riparian forests is limited only by the prolonged summer flooding. Depending on climatic conditions (droughts), onetwo cuts of hay are harvested. For eight years, the scope of mowing is conditioned by agri-environmental programs. Due to the economy, especially grazing, herbaceous plants significantly reduced the area of occurrence. Within the complex of grassland species, there are mainly groups of creeping thistle, nettle, and couch grass. Hygro- and nitrophilous herbaceous species with Molinio-Arrhenatheretea and Artemisietea develop on the outskirts of the oxbow lakes, local wet depressions, and edges of trees.

Leaving the biomass is equivalent to intensive fertilization, and in the case of over-fertilized meadows, it was proved that their performance is negatively correlated with the floristic abundance (van der Bergh 1979, Grime 1979, Oomes \& Moor 1981, Willems 1983, Melman \& VerkaAr 1991). This is also confirmed by the obtained results (Table 2). Only 14 species from the list and only 53 ones from the table, on average, were found in a similar number of records within the herbaceous species. The pasture and grazing phytocenons are floristically the richest (average of 23 species in the record and the up to 92 in the whole table), and among them mainly cnidion meadows (an average of 31 species in the record and 89 in the entire table). Traditional cutting and grazing contribute to the formation and maintenance of diverse vegetation.

In extreme cases, when treading is the limiting factor, from 8 to 16 species in the record and only 20 in the table, were found.
Analysed communities are in similar habitat conditions. In terms of potential natural vegetation, it is mostly the riparian willow, rarely the riparian poplar. Therefore, the floristic abundance is determined by the performance manner.

Creating the Jeziorsko reservoir (1986) significantly reduced the natural activity of the river and contributed to in floods reduction. Consequently, at the expense of more hygrophilous groups, the participation of communities associated in drier habitats that previously found the conditions for their development only on a small, local, and sandy elevations, increases.

In the case of grassland and ruderal communities, habitat is a bit drier and potential natural vegetation predominantly consists of riparian poplar. These groups, especially the grasslands, are formed mainly under the influence of grazing. They are floristically abundant.

Rushes associated with wet biotopes are very poor in terms of species composition. Besides the specificity of habitats, floristic poverty is caused by aggregating occurrence of a characteristic species. In addition to differences in floristic abundance in the analysed types of communities, the domination relations in particular syntaxonomic groups are changing (Table 2).

Degree of conservation of the natural and most of all semi-natural vegetation is within the floodplain high and percentage of communities that are very synanthropic is relatively small. The total synanthropisation ratio of the vegetation is very high and amounts to $87.1 \%$, and the indicator of anthropogenic communities share within vegetation has relatively little value: $40.0 \%$. For comparison, within the studied catchment area of the Główna river - primarily agricultural area, where there are also urban areas, as well as close to natural forests, index of to-

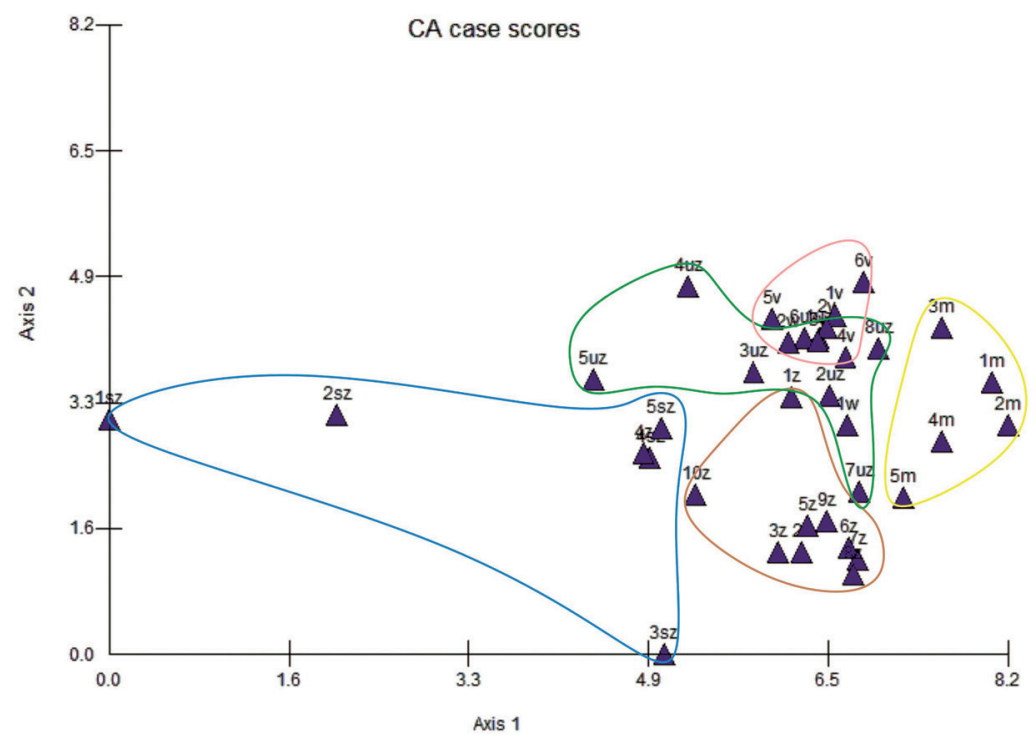

Fig. 5. Results of the indirect analysis DCA (MVSP) 
tal synanthropisation for vegetation is slightly lower and equals to $85.7 \%$. In contrast, the anthropogenic communities participation rate in vegetation is much higher - its value is $53.0 \%$ (RATYŃSKA 2003).

DCA analysis results, in which the arrangement of area is based on phyto-sociological data showed a variation on the first and second axes in $14 \%$. The first ordering axis has the highest value $(8.38 \%)$ and thus it shows the main variation gradient, which is the moisture content (Fig. 5).

KUCHARSKI (1999) emphasizes that on the meadows of Central Poland, populations of moisture-philous species (Caltha palustris, Cirsium oleraceum, C. rivulare, Crepis paludosa, Lathyrus palustris, Myosotis palustris, Angelica sylvestris, Cirsium palustre, Lychnis flos-cuculi, Sanguisorba officinalis, Serratula tinctoria, and Geum rivale) are reduced from year to year. On the other hand, drying the habitats makes that general pasture species (Stellaria graminea, Taraxacum officinale, Galium verum, Senecio jacobea, Cardaminopsis arenosa, Cirsium arvense, Achillea millefolium) and characteristic for grasslands, spread. This phenomenon, to a limited extent (the presence of floods) also takes place in the Warta River valley.

\section{CONCLUSIONS}

- Semi-natural grasslands determined by the many-centuries management, are a place of many species subject to legal protection and endangered ones, and also threatened plant communities and typical for protected habitat types.

- The most significant factors affecting the floodplain vegetation are the prato-technical management and water relations associated with the terrain sculpture and periodic floods.

- Giving up grazing and mowing initiates secondary succession, then it results in reduction of the acreage of meadows and pastures in favour of herbaceous species, and next scrub and woody communities. Thus, the position of grassland species, including protected and endangered ones, disappears.

- The intensification of grazing contributes to changes in floristic composition and structure of communities.

- Fertilization is a less significant factor shaping the floristic and phytocenotic relations within the Warta River valley.

- In order to maintain the existing plant diversity of the Rogalin Łęgi and the landscape values of this section of the Warta River, it is necessary to keep the traditional grassland-pastures management and to provide regular river floods, which both determines water relations and contributes to the natural fertilization.

\section{REFERENCES}

BARABASZ B. (1997): Zmiany roślinności łąk w północnej części Puszczy Niepołomickiej w ciągu 20 lat. Studia Naturae 43.

Barkman J.J., Doing H., Segal S. (1964): Kritische Bemerkungen und Vorschläge zur quantitativen Vegetationsanalyse. Acta Botanica Neerlandica 13: 394-419.

Bednorz J. (1976): Ptaki wodne i błotne zagospodarowanych łąk zalewowych $\mathrm{w}$ dolinie Warty koło Poznania. Zeszyty Naukowe UAM, Seria Zoologia 5: 3-77.

BERGH J.P. van der (1979): Changes in the composition of mixid populations of grassland species. In: M.J.A. Werger (ed.). The study of vegetation. Dr. W. Junk, The Haque: 57-80.

BorYSIAK J. (1994): Struktura aluwialnej roślinności lądowej środkowego i dolnego biegu Warty. Seria Biologia 52. Wyd. UAM, Poznań.

DĄmBSKA I. (1981): O powiększenie Wielkopolskiego Parku Narodowego. Przyroda Polska 9: 14-15.

Denisiuk Z. (1978): Wielkopolski Park Narodowy stan aktualny i perspektywy rozwoju. Chrońmy Przyrodę Ojczystą 34(2): 5-20.

Denisiuk Z., Szoszkiewicz J. (1963): W sprawie ochrony zabytkowych dębów w Rogalinie i występującej tam roślinności. Chrońmy Przyrodę Ojczystą 19(4): 10-21.

Grime J.P. (1979): Plant strategies and vegetation processes. Wiley and Sons, Chichester.

Herbich J. (2004): Poradniki ochrony siedlisk i gatunków Natura 2000 - podręcznik metodyczny. Tom 1-9. Ministerstwo Środowiska, Warszawa.

Hill M.O., Gauch H.G (1980): Detrended correspondence analysis, an improved ordination technique. Vegetatio 42: 47-58.

Jackowiak B., Celka Z., Chmiel J., Żukowski W. (2007): Red list of vascular flora of Wielkopolska (Poland). Biodiversity Research and Conservation 5-8(3-4): 95-127.

Jongman R.H.G. (1996): Ecological and landscape consequences of land use change - Introduction. In: R.H.G. Jongman (ed.). Ecological and landscape consequences of land use change in $\mathrm{Eu}-$ rope. Proceedings of the first ECNC seminar on land use change and its ecological consequences. 16-18 February 1995 Tilburg, The Netherlands. ECNC 2: 9-15.

Kaczmarek A. (1992): Dęby w Rogalinie - żywe pomniki dziejów. Chrońmy Przyrodę Ojczystą 48(3-4): 70-72.

KasprzaK K., PNiewski Z. (1978): O ochronę terasy zalewowej rzeki Warty koło Rogalina. Chrońmy Przyrodę Ojczystą 34(4): 33-41.

KondRACKI J. (1998): Geografia regionalna Polski. Wyd. Nauk. PWN, Warszawa. 
Kornaś J., Dubiel E. (1991): Land use and vegetation changes in hay-meadow in the Ojców National Park during the last thirty years. Veröffentlichungen des Geobotanischen Institutes ETH, Zürich, Stiftung Rübel 106: 209-231.

KovACH W.L. (1999): MVSP - A MultiVariate Statistical Package for Windows, ver. 3.1. Kovach Computing Services, Pentraeth, Wales, U.K.

Król S., AntKowiak W., Bednorz L., Szczepanik-JanyszeK M. (1993): Dęby Rogalińskie, ich stan obecny i perspektywy ochrony. Przegląd Przyrodniczy 4(3): 91-94.

KUCHARSKI L. (1999): Szata roślinna łąk Polski Środkowej i jej zmiany w XX stuleciu. Wyd. Uniwersytetu Łódzkiego, Łódź.

ŁAKOMiec J., Szafrański F. (1997): Rogaliński Park Krajobrazowy. Biuletyn Parków Krajobrazowych Wielkopolski 2(4): 5-9.

MAALER E. van der (1979): Transformation of cover abundance values in phytosociology and its effect on community similarity. Vegetatio 39: 97-144.

Matuszkiewicz J.M. (1993): Krajobrazy roślinne i regiony geobotaniczne Polski. Prace Geograficzne IGiPZ PAN 158.

Melman P.J.M., VerkaAr H.J. (1991): Layout and management of herbaceous vegetation in road verges. In: D. van Bohemen, D.A.G. Buizer, A. Little (eds). Nature engineering and civil engineering works. Ministry of Transport, Public Works and Water Management, Wageningen: 62-78.

Michalik S. (1990): Przemiany roślinności łąkowej w toku sukcesji wtórnej na stałej powierzchni badawczej w Ojcowskim Parku Narodowym. Prądnik, Prace Muzeum Szafera 2: 149-159.

Oomes M.J.M., Moor H. (1981): The effects of cutting and fertilizing on the floristic composition and production of Arrhenatheretum elatioris grassland. Vegetatio 47: 233-239.

RatyŃska H. (2001): Roślinność Poznańskiego Przełomu Warty i jej antropogeniczne przemiany. Wyd. Akademii Bydgoskiej im. Kazimierza Wielkiego, Bydgoszcz.

RATYŃSKA H. (2003): Szata roślinna jako wyraz antropogenicznych przekształceń krajobrazu na przykładzie zlewni rzeki Głównej (środkowa Wielkopolska). Wyd. Akademii Bydgoskiej im. Kazimierza Wielkiego, Bydgoszcz.

RATYŃSKA H., SzWEd W. (1999): Waloryzacja przyrodnicza oraz wskazania ochronne dla terasy zalewowej Warty w parkach krajobrazowych środkowej Wielkopolski. Biuletyn Parków Krajobrazowych 4(6).

Ratyńska H., Wojterska M., Brzeg A., Kołacz M. (2010): Multimedialna encyklopedia zbiorowisk roślinnych Polski. NFOSiGW, UKW, IETI, Bydgoszcz.

RoZPORZĄDZENIE Ministra Środowiska $z$ dnia 13 kwietnia 2010 r. w sprawie siedlisk przyrodniczych oraz gatunków będących przedmiotem zainteresowania Wspólnoty, a także kryteriów wyboru obszarów kwalifikujących się do uznania lub wyznaczenia jako obszary Natura 2000. (2010). Dz.U. nr 77, poz. 510.

RozPORZĄDZENIE Ministra Środowiska z dnia 20 stycznia 2012 r. w sprawie gatunków dziko występujących roślin objętych ochroną. (2012). Dz.U. z 2012 r. nr 0, poz. 81.

Szafer W. (1972): Szata roślinna Polski Niżowej. In: W. Szafer, K. Zarzycki (eds). Szata roślinna Polski. T. 2. Wyd. Nauk. PWN, Warszawa: 17-188.

Szoszkiewicz J. (1966): Zbiorowiska trawiaste łąk łęgowych w dolinie Warty. Zeszyty Problemowe Postępów Nauk Rolniczych 66: 61-70.

Szoszkiewicz J. (1967): Zbiorowiska roślinne łąk łęgowych $\mathrm{w}$ dolinie Warty. A. Zbiorowiska klasy Phragmitetea i Plantaginetea. Prace Komisji Nauk Rolniczych i Komisji Nauk Leśnych PTPN 23(2): 465-501.

Szoszkiewicz J. (1968): Zbiorowiska łąk grądowych w dolinie Warty. B. Zbiorowiska roślinne klasy Molinio-Arrhenatheretea. Prace Komisji Nauk Rolniczych i Komisji Nauk Leśnych PTPN 24: 283-325.

Szoszkiewicz J. (1969): Zbiorowisko łąkowe z Armeria elongata i Festuca ovina w dolinie Warty. Roczniki WSR Poznań, Wydział Rolny 11: 117-129.

Szoszkiewicz J., Denisiuk Z. (1965): Warunki glebowe wazniejszych zbiorowisk łąk łęgowych w dolinie środkowego odcinka Warty. Roczniki Gleboznawcze 15: 375-379.

Walczak M., Radziejowski J., Smogorzewska M., Sienkiewicz J., Gacka-Grzesikiewicz E., Pisarski Z. (2001): Obszary chronione w Polsce. IOŚ, Warszawa.

Willems J.H. (1983): Species composition and above ground phytomass in chalk grassland with different management. Vegetatio 52: 171-180.

Wojtaszek M. (1989). Roślinność starorzeczy prawobrzeżnej doliny Warty w rejonie Rogalina. Badania Fizjograficzne nad Polską Zachodnią Seria B 39: 105-117.

Woś A. (1994): Klimat Niziny Wielkopolskiej. Wydawnictwo Naukowe UAM, Poznań.

ZARZYCKI K., SzeląG Z. (2006): Red list of the vascular plants in Poland. In: Z. Mirek, K. Zarzycki, W. Wojewoda, Z. Szeląg (eds). Red list of plants and fungi in Poland. W. Szafer Institute of Botany, Polish Academy of Sciences, Kraków: 11-20. 